\title{
PENGARUH PROGRAM LATIHAN PENINGKATAN DAYA TAHAN JANTUNG PARU PADA UKM TINJU
}

\author{
Jori Lahinda \\ Universitas Musamus, email: lahinda_fkip@unmus.ac.id \\ Carolus Wasa \\ Universitas Musamus, email:Caro@unmus.ac.id \\ Pulung Riyanto \\ Universitas Musamus, email:vhoelubar@gmail.com
}

\begin{abstract}
Abstrak
Penelitian ini bertujuan untuk mengetahui seberapa besar pengaruh dari latihan interval terhadap daya tahan jantung paru dalam melakukan Shadow Boxing pada kelompok hemoglobin normal pada UKM Tinju mahasiswa. Metode penelitian ini merupakan penelitian Quasi Eksperimental Design yaitu dengan menggunakan One-Group PretestPostest Design. Dengan jumlah sampel sebanyak 20 orang. Berdasarkan hasil analisis data yang diperoleh selama 16 kali pertemuan, latihan interval yang dilakukan memberikan hasil performa daya tahan dalam melakukan Shadow Boxing yang maksimal dengan menggunakan analisis uji-t. Berdasarkan hasil perhitungan uji t diperoleh nilai sig 0,000 < 0,05 dengan thitung $=13,361>$ ttabel $=1.729$. Dari hasil statistik deskriptif HO diterima, dapat dilihat pula ada perbedaan signifikan antara daya tahan jantung paru dalam melakukan Shadow Boxing sebelum dan sesudah latihan interval dengan peningkatan sebesar 35.95 $\mathrm{ml} / \mathrm{kg} / \mathrm{menit}$. Sehingga disimpulkan bahwa ada pengaruh yang signifikan latihan interval terhadap daya tahan jantung paru dalam melakukan Shadow Boxing pada UKM Tinju mahasiswa Penjaskesrek Universitas Musamus.
\end{abstract}

Kata Kunci: Program Latihan, Daya Tahan Jantung Paru, Shadow Boxing

\begin{abstract}
This study aims to determine how much influence the interval training has on the endurance of the pulmonary heart in performing Shadow Boxing in the normal hemoglobin group in UKM Boxing students. This research method is a Quasi Experimental Design research using One-Group Pretest-Postest Design. With a total sample of 20 people. Based on the results of the analysis of data obtained during 16 meetings, the interval training that was performed gave the maximum endurance performance results in Shadow Boxing using t-test analysis. Based on the results of the $t$ test calculations obtained sig value of $0,000<0.05$ with tcount $=$ 13.361 $>$ ttable $=1.729$. From the results of the descriptive statistics $\mathrm{HO}$ is accepted, it can also be seen that there is a significant difference between the endurance of the pulmonary heart in performing Shadow Boxing before and after interval training with an increase of $35.95 \mathrm{ml} / \mathrm{kg} /$ minute. So it was concluded that there was a significant effect of interval training on pulmonary heart endurance in performing Shadow Boxing in Boxing UKM, Penjaskesrek Universitas Musamus
\end{abstract}

Keywords: Training program, Pulmonary Heart Resilience, Shadow Boxing 


\section{PENDAHULUAN}

Tinju ialah salah satu olahraga banyak sekali disukai oleh kalangan masyarakat baik tua dan muda bahkan sekarang ini olahraga tinju bukan hanya dipertandingkan bagi kaum laki-laki saja, tetapi olahraga tinju baik tinju professional maupun amatir telah dipertandingkan bagi kaum perempuan. Menariknya pertandingan tinju bagi penonton jika melihat salah satu petinju terjatuh sehingga tidak dapat melanjutkan pertandingan. Bagi petinju bahkan bagi pelatih kejadian tersebut merupakan satu hal yang sangat mengecewakan.

(Lahinda, 2019) Dalam kehidupan sekarang ini olahraga bukanlah lagi tempat pelarian tetapi sudah menjadi suatu fenomena sosial yang bersumber dalam hati sanubari orang, baik pada generasi muda maupun orang dewasa, baik pria maupun wanita. Oleh sebab itu pendidikan, Olahraga dan kesehatan telah menjadi lapangan pencaharian dan kebudayaan.

(Sajoto, 1995) Tinju, the noble art of selfdefence, adalah salah satu olahraga tertua. Orang Yunani dan Romawi telah melakukannya. Ketika itu orang tidak peduli akan penggunaan tenaga semata-mata pada"anggar kepal" itu. Yang pertama melihat kemungkinannya dijadikan sumber nafkah, lama sesudah itu, ialah guru anggar James Frigg. Dibuatlah peraturan - peratura, di satu pihak untuk melindungi para petinju, di lain pihak untuk membuat tinju menjadi lebih menarik bagi penonton. Para petinju dan pelatih mulai mengerti bahwa tinju bukan hanya tenaga semata-mata, tetapi lebih merupakan olahraga bela diri. Tinju yang tenang,teknis, dan terutama bertahan dengan menampung serangan-serangan, sangat dihargai. Dari situlah julukan the noble art of selfdefence (seni mulia untuk bela diri).
1. Program Latihan

Banyak pelatih dewasa ini dalam memberikan latihan, hanya berdasarkan pengalaman mantan petinju, tidak memiliki pengetahuan tentang ilmu-ilmu yang menunjang pencapaian prestasi, terlebih dalam penyusun program. Banyak pelatih hanya berprinsip bahwa latihan tinju hanya identik dengan memukul, tidak mempertimbangkan faktor pendukung seperti daya tahan jantung paru. Ada dijumpai pelatih yang tidak mampu menyusun bentuk latihan untuk peningkataan daya tahan jantung paru.

Pembinaan latihan fisik sangat penting dalam pencapaian prestasi yang maksimal. Latihan yang teratur dapat mencapai kondisi fisik yang tinggi dan terarah dengan memperhatikan tipe latihan, intensitas, waktu latihan dan frekuensi latihan. Dalam Kondisi fisik ada suatu kompenen yang sangat menentukan prestasi mahasiswa adalah ketahananotot (muscular endurance) dan ketahanan jantung paru (cardiovascular endurance).

(Dwijowinoto, 1993) “Daya tahan jantung paru dapat tercapai ketika adanya peningkatan melalui tenaga aerobik maksimal (Volume Oksigen Max) dan anaerobik. Oleh karena itu dalam meningkatkan daya tahan jantung paru perlu diberikan suatu bentuk pola latihan yang spesifik yang secara efektif dapat lebih menjamin keberhasilan pada cabang olahraga yang ditekuni.

(Harsono, 1988) "Pola latihan yang dilakukan dalam meningkatkan daya tahan jantung paru ialah interval training. Interval training ialah suatu proses latihan yang sangat penting dimasukan kedalam satu agenda latihan.Oleh sebabitu dampak yang baik akan didapatkan bagi perkembangan ketahanan maupun stamina atlet".

Pada akhir pertandingan hampir semua petinju tidak mampu lagi melontarkan pukulan karena tidak memiliki stamina yang baik khususnya daya tahan jantung paru. Hal ini 
sangatlah merugikan karena petinju hanya mampu mengumpulkan angka pada ronde awal, sedangkan mulai dari ronde ketiga sampai terakhir angka tersebut terkejar malah lebih fatal petinju mengundurkan diri atau berakibat KO.

Demi tercapainya prestasi yang diinginkan, dibutuhkan suatu upaya latihan yang ada dalam konsep agenda latihan. Perencanaan program latihan yang baik dapat mempertimbangkan aspek-aspek tersebut antara lain: potensi atlet, umur, jenis kelamin, tingkat kemapuan atlet sarana prasarana dana, waktu yang tersedia, tenaga pelatih dan faktor lingkungan. Sebelum menyusun program latihan, seorang pelatih terlebih dahulu harus menetapkan tujuan yang ingin dicapai secara cermat bagi atletnya agar dalam klimaks pertandingan dapat menampilkan kemampuannya.

Konsep agenda latihan adalah salah satu cara dari seorang pelatih untuk mendapatkan performa terbaik dari atlet dimasa yang akandatang. Hal tersebut seperti diungkapkan oleh Syafruddin bahwa: "Perencanaan latihan adalah merupakan suatu persiapan latihan terdahulu yang disusun secara terarah, teoritis dan berjangka serta terstruktur dalam penyajian materinya". Manfaat penyusunan suatu konsep latihan adalah : 1) Panduan suatu kegiatan yang terstruktur utnuk capaian prestasi suatu cabang olahraga, 2) untuk mendapatkan prestasi yang prima maka harus dihindari yang dikatakan faktor keberuntungan, serta 3) dapat mengatur penggunaan waktu, dana dan tenaga secara tepat untuk mencapai tujuan.

(Koni, 2000) Interval training membutuhkan stamina, intensitas lari biasa rendah sampai sedang, sekitar 50\% - $70 \%$ dan keahlian yang maksimal. Contoh interval training untuk daya tahan jantung pant-pam sebagai berikut:

- Jarak lari: 400 m atau 600 m

- Intensitas kerja: 60\%-70 \% merupakan keahlian yang maksimal.

-Pengulangan lari: 8 - 12 kali
- Waktu jeda sampai denyut nadi 120 - 130 atau sekitar 3 - 5 menit.

Mengingat olahraga tinju merupakan olahraga aerobik, maka daya tahan jantung paru perlu diperhatikan. Untuk bisa mendapatkan daya tahan pada jantung paru yang tinggi, haruslah latihannya memperhatikan tiga faktor yang mendukung, yaitu: Keseriusan latihan, lama latihan dan frekuensi latihan.

2. Volume Oksigen Maksimal/Daya Tahan Jantung Paru

(Sajoto,1995) Cardiovascular endurance ialah kemampuan seseorang mengunakan sistem jantung, paru_paru dan peredaran darahnya secara efektif dan efisien, menjalankan kerja secara kesinambungan yang melibatkan konteraksi sejumlah otot-otot dengan intensitas tinggi dalam waktu yang cukup lama. Hal senada juga dikemukakan oleh (Kasman, 1987) bahwa Volume Oksigen Maksimal merupakan daya tahan system peredaran darah dari pernapasan untuk menempuh suara beban tertentu dengan jangka waktu tertentu.

(Harsono, 1988) Sistem latihan speed play ialah bentuk latihan endurance dimaksud ialah untuk bisa membangun kembali atau memelihara kondisi tubuh seseorang.Begitu juga jeda latihan, sistem latihan ini dapat juga diterapkan pada semua olahraga yang membutuhkan daya tahan dan stamina.

Menyimpulkan dari pendapat yang telah dikemukakan diatas, bahwa Volume Oksigen Maksimal ialah kemampuan seseorang sangat berhubungan dengan jantung, paru dan peredaran darah dalam setiap kali melakukan aktivitas secara berulang-ulang dalam jangka waktu yang cukup lama dengan tidak mengakibatkan kelelahan yang berarti.

Banyak Faktor yang memberikan dampak tentang bagaimana kedayagunaan tubuh untuk bisa menggunakan oksigen pada setiap kali melakukan pekerjaan, misalnya sewaktu olahraga, otot harus menghasilkan energi, satu proses di mana oksigen memegang peranan penting. Menurut Jonathan Kuntaraf bahwa : 
Lebih banyak kita menggunakan oksigen, yang artinya kapasitas yang diberikan lebih besar untuk hasil kerja energi, yang berarti daya tahan yang dihasilkan pula begitu besar. Jika semakin baik pada ketahanan jantung peredaran darah kita, otot-otot juga dapat bertahan lebih lama untuk menjalankan fungsinya. Dengan kata lain bahwa lebih banyak oksigen, maka lebih banyak pula energi yang dihasilkan sehingga otot dapat melakukan fungsi dalam waktu yang lama.

3. Tinju

(Kasman, 1987) Ketika belajar untuk membiasakan bertinju, oleh pelatih harus dididik dari dasar yang tetap. Pelatih harus bertolak dari teknik yang seragam, ia harus mendapat pelajaran dan latihan pada pendidikan yang baik disertai banyak pengalaman. Tinju adalah olahraga yang sukar diajarkan dan dibiasakan. Gaya bertinju masing-masing petinju berbeda atau memiliki teknik masing-masing, dimana kedua pihak mencoba menguasai gerakan lawan melalui gerak teknis dan siasat di sertai kemampuan taktik dan fisik seperti kekuatan, kelincahan, keseimbangan, kelentukan, power, dan kecerdasan dalam bertinju.

Sikap sedia atau sikap tinju (stand of boxing) adalah suatu sikap yang dasar harus dimiliki oleh seorang petinju dalam penampilannya diatas ring. Sikap dasar tinju ini di bagi dalam lima bagian yaitu : (a) kepalan, (b) sikap tinju, (c) foot work, (d) pukulan dan elakan, (e) koordinasi foot work dan pukulan.

Dari uraian yang sudah dikemukakan di atas maka dijadikan fokus permasalahan dalam penelitian ini adalah Pengaruh program latihan terhadap meningkatan daya tahan jantung paru pada UKM Tinju Mahasiswa penjaskesrek Universitas Musamus Tahun 2019.

\section{METODE}

(Sugiyono, 2012) Metode yang dipakai dalam penelitian ini merupakan "Quasi Eksperimental Design" yaitu dengan menggunakan "One-Group Pretest-Postest Design". kemudian dilakukan Pretest dan
Posttest. Untuk lebih jelasnya, pelaksanaan peneliti membuat desain penelitian.

Tabel 2. One-Group

\begin{tabular}{c|c|c}
\hline Pre-test & Treatmen & Post-Test \\
\hline $\mathrm{O}_{1}$ & $\mathrm{X}$ & $\mathrm{O}_{2}$ \\
\hline
\end{tabular}

Populasi adalah mahasiswa UKM tinju penjaskesrek sebanyak 20 orang dan sampel di ambil dari keseluruhan jumlah populasi. Interval training merupakan bentuk latihan yang diberikan kepada kelompok eksperimen selama 16 minggu.Adapun bentuk latihan yang diberikan adalah latihan lari dengan jarak 400 meter-600 meter dengan intensitas 60\%-70\% dari kemampuan maksimal. Latihan deberikan dengan repetisi 8-12 kali dan dilakukan sebanyak 3 set, istirahat tiap repetisi 3 menit. Setelah dilaksanakan pengambilan data, maka data ini akan dihitung dengan teknik analisis data menggunakan uji t

\section{HASIL DAN PEMBAHASAN}

Hasil

Subjek dalam penelitian ini adalah UKM Tinju mahasiswa jurusan Penjaskesrek yang berjumlah dua puluh orang. Mengawali penelitian ini dilaksanakan dengan pengambilan data pretest pada 27 september 2019, dan kemudian diberikan treatmen untuk meningkatkan volume oksigen maksimal dalam melakukan shadow box, serta dilanjutkan dengan pengambilan data posttest pada tanggal 28, 30 oktober 2019 dan 04 november 2019. Variable data yang diambil dalam penelitian ini difokuskan pada Shadow Boxing.

Tabel 2. Hasil Pretest dan Posttest

\begin{tabular}{l|l|c|c}
\hline & \multicolumn{2}{|c|}{ Nilai Rata-Rata } & $\begin{array}{c}\text { Nilai } \\
\text { Peningkatan }\end{array}$ \\
\hline & Pretest & Posttest & $45 \%$ \\
\hline Vo2Max & 32.50 & 77.50 & \\
\hline
\end{tabular}

Hasil tes yang dilakukan pada sampel sebelum diberikan perlakuan dan sesudah diberikan perlakuan, diketahui bahwa nilai rata-rata pretest Vo2 Max dalam melakukan Shadow Box adalah 32.50, untuk nilai rata-rata 
posttest Vo2Mas dalam melakukan Shadow Box adalah 77.50, sehingga peningkatannya adalah 45\%. Untuk lebih jelasnya disajikan histogram tentang deskriptif Vo2Max dalam melakukan Shadow Boxing.

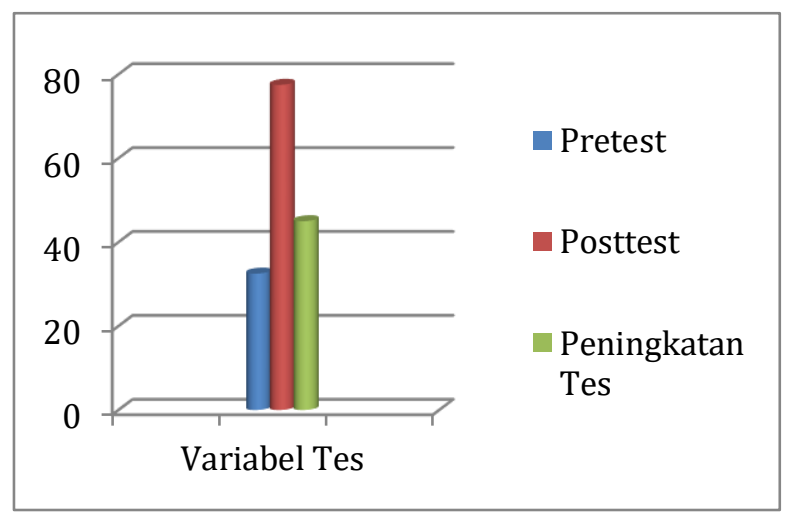

Gambar 1. Histogram

Tabel 3. Normalitas Data

Tests of Normality

\begin{tabular}{c|c|c|r|r|r|r}
\hline & \multicolumn{3}{|c|}{$\begin{array}{c}\text { Kolmogorov- } \\
\text { Smirnov }^{\text {a }}\end{array}$} & \multicolumn{3}{c}{ Shapiro-Wilk } \\
\cline { 2 - 7 } & $\begin{array}{c}\text { Statist } \\
\text { ic }\end{array}$ & Df & \multicolumn{1}{c|}{ Sig. } & Statistic & df & Sig. \\
\hline $\begin{array}{c}\text { pretes } \\
\text { t }\end{array}$ & .171 & 20 & .126 & .906 & 20 & .054 \\
\hline $\begin{array}{c}\text { postte } \\
\text { st }\end{array}$ & .153 & 20 & $.200^{*}$ & .951 & 20 & .378 \\
\hline
\end{tabular}

Data yang dihasilkan dapat dikatakan normal apabila memiliki nilai $p$ (Sig.) $>0.05$. setelah dilakukan uji normalitas didapatkan hasil nilai $p$ (Sig.) > 0.05. maka variable berdistribusi normal.

Tabel 4. Uji Hipotesis

\begin{tabular}{|c|c|c|c|c|c|c|c|}
\hline \multicolumn{5}{|c|}{ Paired Differences } & $\mathbf{t}$ & $\begin{array}{l}d \\
f\end{array}$ & $\begin{array}{l}\text { Sig. } \\
\text { (2- } \\
\text { taile } \\
\text { d) }\end{array}$ \\
\hline \multirow{2}{*}{$\begin{array}{c}\text { Me } \\
\text { an }\end{array}$} & \multirow{2}{*}{$\begin{array}{l}\text { Std. } \\
\text { Deviat } \\
\text { ion }\end{array}$} & \multirow{2}{*}{$\begin{array}{l}\text { Std. } \\
\text { Error } \\
\text { Mean }\end{array}$} & \multicolumn{2}{|c|}{$\begin{array}{c}95 \% \\
\text { Confidence } \\
\text { Interval of the } \\
\text { Difference }\end{array}$} & & & \\
\hline & & & Lower & Upper & & & \\
\hline $\begin{array}{r}35 . \\
95\end{array}$ & 2.03274 & $\begin{array}{r}2.6906 \\
0\end{array}$ & $\begin{array}{r}30.318 \\
50\end{array}$ & $\begin{array}{r}41.581 \\
50\end{array}$ & $\begin{array}{r}13 . \\
36\end{array}$ & $\begin{array}{l}1 \\
9\end{array}$ & .000 \\
\hline
\end{tabular}

Berdasarkan thitung $=13.361$ dan nilai $t_{\text {tabel }}$ dari df $19=1.729$ maka, $t_{\text {hitung }}>$ dari $t_{\text {tabel }}$ berdasarkan dari hasil statistik deskriptif $\mathrm{HO}$ diterima, maka dalam penelitian ini terdapat pengaruh program latihan peningkatan daya tahan jantung paru pada ukm mahasiswa tinju penjaskesrek universitas musamus.

\section{Pembahasan}

Program latihan tinju di UKM tinju mahasiswa Penjaskesrek Universitas Musamus mengarah pada latihan daya tahan diantaranya: 1) latihan interval training, 2). circuit training. Kegiatan circuit training dilakukan selama 12 menit dengan repetisi 3 kali perlakuan, setelah itu dilanjutkan dengan shadow boxing ( 3 menit). Selama latihan, mahasiswa sangat antusias dalam setiap melakukan tahapan gerakannya, meskipun menguras energy yang banyak, namun obsesi untuk meningkatkan prestasi. Untuk menstimulasi motivasi pada mahasiswa UKM tinju, keseluruhan latihan diakhiri dengan shadow box dua ronde yang dilakukan selama 3 menit. Peningkatan ini di dasari oleh dorongan motivasi. Motivasi sebagai suatu keadaan dalam pribadi orang yang mendorong individu untuk melakukan aktivitas-aktivitas tertentu guna mencapai suatu tujuan. Jadi, motivasi bukanlah hal yang diminati, tetapi adalah hal yang dapat di simpulkan adanya karena sesuatu yang dapat kita saksikan. Tiap aktivitas yang dilakukan seseorang itu didorong oleh sesuatu kekuatan dari dalam diri orang itu, kekuatan pendorong inilah yang kita sebut motivasi (Fadlih \& Riyanto, 2019).

Berdasarkan hasil data variable daya tahan jantung paru atau VO2Max dengan melakukan Pukulan shadow box, dengan nilai minimal 47.0 dan nilai maksimal 100. Banyak faktor yang mempengaruhi daya tahan dalam melakukan pukulan Shadow Box diantaranya daya tahan jantung paru sangat rendah dikarenakan mahasiswa UKM Tinju sering tidak hadir mengikuti jadwal latihan dan tidak sepenuhnya mengikuti program latihan dengan benar. 
Latihan shadow box merupakan latihan dasar yang harus diberikan dalam permainain tinju. Shadow box juga harus di dasari dengan tingkat kebugaran jasmani yang di miliki oleh pemain tinju. In Shadow Boxer, the user is supposed to use the basic movements of fitness boxing. These include three kinds of punches (straight hits, uppercuts, and hook punches) and sideways movement (Höysniemi, Aula, Auvinen, Hännikäinen, \& Hämäläinen, 2004).

Shadow box yang dikembangkan dalam latihan, diaplikasikan untuk mendukung terhadap permainan yang professional dalam cabang olahraga tinju. Dilihat dari analisis mekanika Gerakan ini sangat mendukung dalam permainan pemain professional. Hal ini bisa terlihat dalam kecepatan pukulan, durasi. have studied some biomechanical characteristics of a straight punch, executed by a heavy weight professional boxer. These parameters were punch velocity at the point of contact, impact force and duration(Cheraghi, 2014).

Pelatihan shadow box harus dilakukan dengan bertahap dalam latihan ,hal ini akan berdampak pada otot-otot yang bekerja. Latihan shadow box juga di pengaruhi oleh aspek lain, diantara berkaitan dengan mental, sehingga dalam latihan akan terjadi perpaduan dalam otot, pikiran yang akan mendukung dalam pencapian latihan yang maksimal. Latihan shadow box juga harus memperhatikan glove dimana dalam latihan luarnya longgar dan lambat sehingga akan menimbulkan kesadaran yang baik dalam melakukan latihan. In the external technical training of Shadow boxing, for the body's muscles, the human body should be gradually deepened through the conscious thinking, so that the natural body to achieve the training of physical and mental awareness of internal awareness training. In the actual combat of Shadow boxing, especially its outer layer is loose and slow and slow, so that the conscious mode of thinking can be displayed vividly (Shu, 2017).
Selain dikembangkan dalam latihan tinju shadow box juga dikembangkan dalam meningkatkan kapasitas jantung paru dalam usia lanjut. Tujuan dari latihan shadow box juga dapat menurukan resistensi pembuluh darah kapiler. Have discovered that long- term Shadow boxing practice has a positive effect on the improvement of heart and lung function in middle aged and elderly people. The research has showed that the peripheral vascular resistance decreases, the peripheral circulation improves after practicing Shadow boxing, and it has a good health care effect on the elderly with peripheral circulation disorders. Medicine and health are the main research and development directions of Shadow boxing (HaiLi, Hai-Jun, \& Xin-Ke, 2019).

Hasil latihan yang maksimal tidak hanya dikembangkan dengan sentuhan bisa, teknologi mempunyai peran dan dukungan yang maksimal dalam meningkatkan prestasi. Peningkatan prestasi ini terutama dalam peningkatan daya tahan paru. Selain dikembangkan dalam latihan hasil dalam latihan juga bisa dikembangkan dalam pembelajaran.Aspek dalam Pendidikan telah ada dalam sentuhan teknologi, hal ini akan berdampak pada kemudahan dalam mengakses informasi. Sentuhan dalam tekonolgi ini akan berdampak pada keterlibatan siswa dalam proses pembelajaran (Riyanto, 2019)

\section{PENUTUP}

Latihan shadow box merupakan latihan dasar yang harus diberikan dalam permainain tinju. Shadow box juga harus di dasari dengan tingkat kebugaran jasmani yang di miliki oleh pemain tinju, dengan sampel yang berjumlah 20 orang. Dari hasil analisis yang diperoleh data Volume Oksigen Maksimal dalam melakukan Shadow Boxing sebelum diberikan perlakuan diperoleh median sebesar 32.50; Sd=16.78494; dengan nilai maksimal 84.0 dan nilai minimalnya 17.0. Pola pemberian program latihan interval dilakukan 16 kali pertemuan sehingga dalam latihan interval yang dilakukan dapat 
memberikan hasil performance daya tahan dalam melakukan Shadow Boxing yang maksimal dan diperoleh median sebesar 77.50; $\mathrm{Sd}=15.75269$; dengan nilai maksimal= 100; dan nilai minimal $=47.0$. Dengan $t_{\text {hitung }}=13.361$ dan nilai $t_{\text {tabel }}$ dari df $19=1.729$ maka, $t_{\text {hitung }}>$ dari $t_{\text {tabel. }}$ Dapat kita lihat pula adanya perbedaan signifikan antara Volume Oksigen Maksimal dalam melakukan Shadow Boxing sebelum diberikan teatmen dan sesudah diberikan latihan interval dengan peningkatan $=35.95$ $\mathrm{ml} / \mathrm{kg} /$ menit. Sehingga dapat ditarik suatu kesimpulkan bahwa adanya pengaruh yang besar pada latihan interval terhadap Volume Oksigen Maksimal dalam melakukan Shadow Boxing pada UKM Tinju mahasiswa Penjaskesrek Universitas Musamus.

\section{DAFTAR PUSTAKA}

Cheraghi, M. (2014). Kinematics of straight right punch in boxing. Annals of Applied Sport Science, 2(2), 39-50.

Dwijowinoto. (1993). Dasar-Dasar Ilmiah Kepelatihan. Semarang: IKIP Semaang Press.

Fadlih, A. M., \& Riyanto, P. (2019). Minat dan Motivasi Peserta Didik Penyandang Disabilitas Ketunarunguan terhadap Mata Pelajaran Pendidikan Jasmani Kesehatan dan Olahraga. Musamus Journal of Physical Education and Sport (MJPES), 2(01), 68-76.

Hai-Li, Z., Hai-Jun, Z., \& Xin-Ke, L. (2019). Research on the effects of long-term shadowboxing practice on the lipid metabolism and related hormone of obese university students from medical perspectie. Acta medica mediterranea, 35(3), 1269-1274.

Harsono. (1988). Coaching Dan Aspek-Aspek Psikologis Dalam Coaching. Jakarta: Tambak Kusuma.

Höysniemi, J., Aula, A., Auvinen, P., Hännikäinen, J., \& Hämäläinen, P. (2004). Shadow boxer: a physically interactive fitness game. In Proceedings of the third Nordic conference on Human-computer interaction (pp. 389-392). ACM.

Kasman, A. (1987). Tinju Aspek Pembinaan Prestasi. Pekanbaru: Medio June.

Koni. (2000). Gerakan Nasional Garuda Emas. Jakarta.

Lahinda, J. (2019). Kontribusi Daya Ledak Otot Tungkai, Kelentukan Togok Belakang Dengan Kekuatan Otot Lengan Terhadap Kemampuan Jump Service. Musamus Journal of Physical Education and Sport, 1(1).

Riyanto, P. (2019). Pengaruh Model Pembelajaran Jigsaw Terhadap Peningkatan Kemampuan Drible Bola Basket. Musamus Journal of Physical Education and Sport (MJPES), 2(01), 5967.

Sajoto, M. (1995). Peningkatan Dan Pembinaan Kekuatan Kondisi Fisik Dalam Olahraga. Semarang: Dahara Prize.

Shu, X. (2017). An Interpretation of Shadowboxing from the Perspective of Perceptual Phenomenology. In 2017 3rd International Conference on Humanities and Social Science Research (ICHSSR 2017). Atlantis Press.

Sugiyono. (2012). Statistika Untuk Penelitian. 